\title{
The characteristics of spelling learning tools oriented to increasing higher order thinking skills in elementary schools
}

\author{
Main Sufanti ${ }^{a, 1^{*}}$, Markhamah ${ }^{\text {b, } 2 \text {, Winarni }}{ }^{\text {c, } 3}$ \\ a Prodi MPBI, FKIP, Universitas Muhammadiyah Surakarta \\ ${ }^{b}$ Prodi PBSI, FKIP, Universitas Muhammadiyah Surakarta \\ ' Prodi MPBI, FKIP, Universitas Muhammadiyah Surakarta \\ Imain.sufanti@ums.ac.id; ${ }^{2}$ markhamah@ums.ac.id; ${ }^{3}$ winwinahyu@gmail.com.
}

*korespondensi penulis

\begin{tabular}{ll}
\hline \multicolumn{2}{l}{ Article's information } \\
\hline History: & \\
Submitted & $:$ I I September 2020 \\
Revised & $:$ 24 April 202I \\
Published & $:$ 30 April 202I
\end{tabular}

Kata kunci:

Karakteristik

Perangkat pembelajaran

Ejaan

Berpikir tingkat tinggi

\section{ABSTRAK}

Tujuan penelitian ini untuk mendeskripsikan karakteristik silabus pembelajaran ejaan berorientasi pada peningkatan kemampuan Berpikir Tingkat Tinggi (BTT) di SD; mendeskripsikan karakteristik RPP pembelajaran ejaan berorientasi pada peningkatan kemampuan BTT di SD; mendeskripsikan karakteristik LKPD pembelajaran ejaan berorientasi pada peningkatan kemampuan BTT di SD; dan mendeskripsikan karakteristik penilaian pembelajaran ejaan berorientasi pada peningkatan kemampuan BTT di SD. Penelitian ini termasuk dalam penelitian deskriptif kualitatif. Data dan sumber data dalam penelitian ini adalah perangkat pembelajaran ejaan berorientasi pada peningkatan kemampuan BTT di SD. Data dalam penelitian ini dikumpulkan dengan teknik dokumentasi, FGD, dan kuesioner. Triangulasi teori dan sumber digunakan untuk memvalidasi data. Teknik analisis interaktif sebagai teknik analisis data. Hasil penelitian menunjukkan silabus pembelajaran ejaan berorientasi pada peningkatan kemampuan BTT di SD memiliki karakteristik mengembangkan kecakapan abad2I, fokus-terpadu, aktual dan kontekstual, fleksibel, dan layak; RPP pembelajaran ejaan berorientasi pada peningkatan kemampuan BTT di SD memiliki karakteristik: keterpaduan, mendalam, dan kekinian; LKPD pembelajaran ejaan berorientasi pada peningkatan kemampuan BTT di SD memiliki karakteristik: fokus, mengaktifkan siswa, dan menarik; Penilaian pembelajaran ejaan untuk meningkatkan BTT siswa sekolah dasar memiliki karakteristik: stimulus kontekstual dan menyeluruh.

Key words:

Characteristics

Learning Media

Spelling

Higher order thinking skills

\section{ABSTRACT}

The purpose of this study was to describe the characteristics of a spelling learning syllabus oriented towards improving Higher Order Thinking (Berpikir Tingkat Tinggi/BTT) skills in elementary schools; describe the characteristics of lesson plans for spelling learning oriented towards improving BTT abilities in elementary schools; describe the characteristics of the spelling learning LKPD oriented towards improving BTT abilities in elementary schools; and describe the characteristics of the spelling learning assessment oriented towards improving BTT abilities in elementary schools. This research is included in qualitative descriptive research. The data and data sources in this study were spelling learning tools oriented towards improving BTT skills in elementary schools. The data in this study were collected using documentation techniques, FGD, and questionnaires. The theory and source triangulation were used to validate the data. Interactive analysis techniques as data analysis techniques. The results showed that the spelling learning syllabus was oriented towards improving BTT abilities in elementary schools which had the characteristics of developing 2I st century skills, focused-integrated, actual and contextual, flexible, and feasible; The lesson plan for spelling learning is oriented towards improving BTT abilities in elementary schools. It has the following characteristics: integrated, deep, and contemporary; Spelling learning LKPD oriented to improving BTT abilities in SD has the following characteristics: focus, activate students, and be interesting; Assessment of spelling learning to improve the BTT of elementary school students has the following characteristics: a contextual and holistic stimulus 


\section{Introduction}

The increasingly complex challenges of education in the future need to be responded quickly. This response is urgent, especially in the era of education in the 2Ist century, where disruption is running rapidly. The results of ongoing research to answer learning needs in the digital era show that it is crucial for students to master 4Cs skills, namely creativity thinking and innovation, critical thinking and problem solving, communication, and collaboration (Ariyana et al., 2019). One of the basic skills students need to face the 2Ist century is critical thinking skills.

Higher Order Thinking (Berpikir Tingkat Tinggi/BTT) as an indicator of critical thinking is the teachers' homework in defining students' needs so that they can develop according to the needs of the times. Thought process (Anderson \& Krathwohl, 2015) is defined as a dynamic thought process that needs to be expressed in the form of a verb. The thought process results in a classification of thought processes either as BTT or low order thinking. The abilities included in the BTT consist of the ability to analyze, to evaluate and to create. The cognitive domain which includes the ability to analyze, the ability to evaluate, and the ability to create is classified as one of BTT skills (Narayanan \& Adithan, 2015).

Planning lessons appropriately is one of the strategies used by teachers in building and developing students' thinking skills (Julistiawati \& Yonata, 2013). The various components of the learning device need to be compiled by the teacher. This is a strategy to achieve the goals of learning activities. In order for teachers to be able to carry out learning interactions in learning activities between students, teachers, and learning resources, they need to create learning tools used in learning processes (Sufanti, Santoso, et al., 2017). The documents included in the learning instrument are syllabus documents, lesson plans, teaching materials, student activity sheets (lembar kegiatan peserta didik/LKPD), and evaluation sheets (Susanto, 2012). A draft that has accommodated the BTT concept has the potential to create learning that encourages students to think at higher orders. This is in line with Permendikbud Number 65 of 2013 concerning Basic and Secondary Education Process Standards so that the learning process accommodates multidimensional learning. This can be realized by preparing children to think at higher orders.

Learning in elementary schools at this time has to implement integrated thematic-based learning. This is an approach that believes that learning should link themes with several subjects (Sufanti, Wahyudi, et al., 2017). This has implications for more meaningful learning for students. More broadly, theme-based learning is learning that crosses the boundaries of subjects in general with the intention of focusing more on life's more comprehensive problems (Hidayah, 20I5). Therefore, it can be synthesized that learning with a thematic approach is learning that connects a theme with several subjects so that learning is more meaningful; in short, learning that is contextual and more comprehensive.

The use of the thematic approach in elementary schools needs to be adjusted to the level of development of students. Curriculum development is carried out by each school with student-centered competency development (Heni et al., 2015). In addition to providing convenience for students, theme-based learning serves to encourage students to learn. This is because the learning carried out is based on real life and has meaning for students. Another function of theme-based learning is to increase the attention of students on a particular theme that is directly related to the real context in the field.

One of the materials taught to elementary school students is spelling. Spelling is one of the various main materials for learning Bahasa Indonesia. Spelling according to Prihantini, (2015:104) is the whole rules related to the symbol of the sound of the speech and the interrelationship between one symbol and another. Tarigan, (2009:2) summed up the simple definition of spelling as a rule for writing words with letters based on linguistic rules. Spelling accurately is basically a good and correct use of Bahasa Indonesia. The basis for using Bahasa Indonesia spelling is the Pedoman Umum Ejaan Bahasa Indonesia (PUEBI/lit:: general guidelines for Bahasa Indonesia spelling) (PUEBI). This is stated in Permendikbud Number 50 of 20I5. This regulation indicates the importance of using proper spelling.

Unfortunately, learning spelling in elementary schools still encountered several problems. Some teachers still did not understand the concept of spelling and effective sentences. Based on the results of the initial test, there were $20 \%$ of teachers who had good ability in using spelling including punctuation in official letters while only $25 \%$ of teachers had good skills in using effective sentences (Supriyana et al., 2016). Meanwhile, the fourth grade students' mistakes in using spelling were the writing of capital letters in the middle of a sentence because the students did not understand, the students were poorly taught, the learning motivation was low, the responses were lacking, and the students' attitudes in learning interactions were low (Rulviana, 2020). Based on these facts, a learning tool that focuses on learning spelling is needed.

There are four objectives in this study. The four objectives are to describe the characteristics of a spelling learning syllabus oriented towards improving higher order thinking skills in elementary schools; describe the 
characteristics of spelling lesson plans to improve thinking skills of elementary school students; to describe the characteristics of the spelling learning activity sheet (LKPD) oriented towards improving higher order thinking skills in elementary schools; and to describe the characteristics of spelling learning oriented towards improving higher order thinking skills in elementary school.

The contribution of this research is expected to be useful as a reference in formulating learning tools oriented towards increasing students' ability to think critically. More specifically, this research can be used as a reference in the preparation of Bahasa Indonesia learning tools oriented towards increasing critical thinking skills through spelling materials.

\section{Method}

This was a qualitative descriptive research. Qualitative research examines a specific object of the data collection process and data sources with a purpose; the process of qualitative data analysis is carried out inductively and the research findings are presented by means of data descriptions (Sugiyono, 2015:9). The data in this study were in the form of words, sentences, paragraphs listed in spelling learning tools that had been developed to improve the higher order thinking skills of elementary school students. In addition, there were data in the form of information from teachers and experts. The data sources were the developed learning tools, elementary school teachers, elementary school students, and Bahasa Indonesia learning experts in elementary schools. The learning tools consisted of a syllabus, lesson plans, worksheet/LKPD, and assessment sheets. Data collection techniques used document analysis techniques, FGD, and questionnaires. Data analysis was performed using interactive techniques Miles et al., (2014:14) consisting of data reduction, data presentation, and drawing conclusions. Data reduction in this study was carried out by focusing on data, namely spelling learning tools oriented to improving higher order thinking skills. The presentation of this research is in the form of a description of findings about learning tools oriented towards increasing higher order thinking skills. The next step is drawing conclusions based on the first and second steps i.e., data reduction and data presentation.

\section{Results and discussion}

This research produced spelling learning tools that were used to assist elementary students in improving their higher order thinking skills. The tools mentioned are the syllabus, lesson plans, LKPD and assessment. The data description was described as follows:

I. Syllabus

The syllabus is a curriculum development product which is the result of the translation of KI (core competencies/kompetensi intr) and $\mathrm{KD}$ (basic competencies/ kompetensi dasar) in schools. Based on the results of the FGD, it was found that practical spelling learning tools were needed to be implemented. Teachers need a learning device model that is suitable to be applied in elementary schools that specifically focuses on spelling material and can be used to improve students' thinking skills, especially higher order thinking.

The format of the syllabus was created based on identity; core competencies; lesson content; basic competencies; character; learning indicators; main materials; activities in learning; learning assessment which includes assessment techniques, types of assessment, and forms of assessment; learning time; and the resources used for learning. Core competencies are formulated in accordance with Permendikbud Number 2I of 2016.

The selected basic competencies were adjusted to the theme network closest to the students which is the interview text. The selection of the interview text topic was also in accordance with the scope of spelling material in elementary schools which includes the use of capital letters and punctuation marks. The operational verb 'menggali (lit. to dig)' from the basic competencies of Bahasa Indonesia is developed with the following indicator operational verbs.

3.3.I Marking the use of spelling in interview texts.

3.3.2 Specifying spelling usage in interview texts.

3.3.3 Analyzing the use of wrong capital letters in interview texts.

3.3.4 Correcting the use of wrong capital letters in interview texts.

The formulation of indicators of competency achievement was presented in stages, starting from key indicators to complementing with supporting and enrichment indicators. The operational verb "menggali (lit. to dig)" is developed with the key indicator "menganalisis (lit. to analyze)". Supporting indicators in the form of KKO "menandai (lit. to mark)" and "melakukan (lit. to do)". KKO 'memperbaiki (lit. to correct)' and 'melakukan' were the complex or enrichment $\mathrm{KKO}$ with the highest difficulty level. 
The characters chosen were in accordance with the core competencies of spiritual attitudes related to religious attitudes and cooperation. The character selection was also adjusted to the PPKn lesson content theme network which raised the topic of rights and obligations in practicing religion in society.

he main material that focuses on spelling is then linked to topics which became network themes which related to the environment. The material was tied using a thematic approach. An integrative thematic approach was used with the main focus on spelling material by integrating PPKn content material rights and obligations to the environment. IPA (natural science) content was as interview material content related to environmental conservation efforts. The contents of IPS (social science) was as the content of the interview text regarding the use of living natural resources.

The learning activity column contained the learning model and its syntax. The learning models chosen were discovery learning (DL), problem based learning (PBL), and project based learning models. Learning activity I used the DL model with stimulation syntax/providing stimulation to students, statements/identifying problems, collecting data, processing collected data, proving data based on findings, and generalizing/drawing conclusions. Learning activity 3 and 4 used the PBL model with the stages of student orientation to the problem, organizing students to learn, guiding individual/group investigations, developing and presenting work, and analyzing and evaluating the problem-solving process. Learning activity 6 developed a project-based learning model with the syntax of formulating questions, compiling project designs, making schedules, controlling project progress, testing processes and learning outcomes, and evaluating experiences.

The assessment plan in the syllabus included the technique, type and form of assessment. The domains of knowledge were assessed by a multiple choice written test. Skills are assessed using a non-test-type performance technique. Learning resources were varied. Learning resources included PUEBI, teaching materials, media, interview texts, and people in the surrounding environment. Media on learning resources used videos and slides. The following is the look of the spelling learning syllabus.

\section{SILABUS PEMBELAJARAN}

$\begin{array}{ll}\text { Satuan Pendidikan } & : \text { SDIT Izzatul Islam Getasan } \\ \text { Kelas/Semester } & : 4 \text { (Empat)/1 } \\ \text { Tema/Subtema } & : \text { 3. Peduli Terhadap Makhluk Hidup/3. Ayo, cintai lingkungan! } \\ \text { Pembelajaran } & : \text { 3 ( Bahasa Indonesia, IPA) }\end{array}$

Kompetensi Inti

1. Menerima, menjalankan dan menghargai ajaran agama yang dianutnya

2. Memiliki perilaku jujur, disiplin, tanggung jawab, santun, peduli, dan percaya diri dalam berinteraksi dengan keluarga, teman, guru dan tetangganya

3. Memahami pengetahuan faktual dengan cara mengamati (mendengar, melihat, membaca) dan menanya berdasarkan rasa ingin tahu tentang dirinya, makhluk ciptaan Tuhan dan kegiatannya, dan benda-benda yang dijumpainya di rumah, sekolah dan tempat bermain.

4. Menyajikan pengetahuan faktual dalam bahasa yang jelas, sistematis dan logis, dalam karya yang estetis, dalam gerakan yang mencerminkan anak sehat, dan dalam tindakan yang mencerminkan perilaku anak beriman dan berakhlak mulia.

\begin{tabular}{|c|c|c|c|c|c|c|c|c|c|c|}
\hline \multirow{2}{*}{$\begin{array}{l}\text { Muatan } \\
\text { Pelajaran } \\
\end{array}$} & \multirow{2}{*}{\begin{tabular}{|l} 
Kompetensi \\
Dasar
\end{tabular}} & \multirow{2}{*}{ Karakter } & \multirow{2}{*}{ Indikator } & \multirow{2}{*}{$\begin{array}{l}\text { Materi } \\
\text { Pokok }\end{array}$} & \multirow{2}{*}{ Kegiatan pembelajaran } & \multicolumn{3}{|c|}{\begin{tabular}{|l} 
Penilaian \\
\end{tabular}} & \multirow{2}{*}{$\begin{array}{l}\text { Alokasi } \\
\text { Waktu }\end{array}$} & \multirow{2}{*}{$\begin{array}{l}\text { Sumber } \\
\text { Belajar }\end{array}$} \\
\hline & & & & & & \begin{tabular}{|l} 
Teknik \\
\end{tabular} & \begin{tabular}{|l|l|} 
Jenis \\
\end{tabular} & Bentuk & & \\
\hline $\begin{array}{l}\text { Bahasa } \\
\text { Indonesia }\end{array}$ & $\begin{array}{l}3.3 \text { Menggali } \\
\text { informasi dari } \\
\text { seorang tokoh } \\
\text { melalui } \\
\text { wawancara } \\
\text { menggunakan } \\
\text { daftar pertanyaan }\end{array}$ & $\begin{array}{l}\text { Religius: } \\
\text { menjalankan } \\
\text { ajaran agama } \\
\text { sesuai yang dianut } \\
\text { Kerjasama: } \\
\text { bekerja sama } \\
\text { dalam }\end{array}$ & $\begin{array}{l}\text { 3.3.3 Menganalisis } \\
\text { penggunaan huruf kapital } \\
\text { yang salah dalam teks } \\
\text { wawancara } \\
\text { 3.3.4 Memperbaki } \\
\text { penggunaan huruf kapital } \\
\text { yang salah dalam teks } \\
\text { wawancara }\end{array}$ & $\begin{array}{l}\text { Penggunaan } \\
\text { huruf kapital } \\
\text { dalam teks } \\
\text { wawancara }\end{array}$ & $\begin{array}{l}\text { Model pembelajaran } \\
\text { Problem Based Learning } \\
\text { 1) Orientasi peserta didik } \\
\text { pada masalah; } \\
\text { 2) Mengorganisasikan } \\
\text { peserta didik untuk } \\
\text { belajar; }\end{array}$ & Tes & \begin{tabular}{|l} 
Tes \\
tertulis
\end{tabular} & $\begin{array}{l}\text { Pilihan } \\
\text { ganda }\end{array}$ & $\begin{array}{l}2 \times 35 \\
\text { menit }\end{array}$ & \begin{tabular}{|l} 
PUEBI \\
Teks \\
Wawancara
\end{tabular} \\
\hline
\end{tabular}

Figure I. Spelling Learning Syllabus

The results of expert validation on the syllabus included four aspects, namely components, linkages between components, linkages with learning principles, and linkages with higher order thinking skills. Validation of the syllabus by learning experts obtained scores of $95.78 \%$ and $85.26 \%$ by material experts. Based on this, it can be concluded that the syllabus had a good level of feasibility for use in spelling learning (Akbar, 20I3:I55).

Based on this, it is concluded that the spelling learning syllabus oriented to high-level thinking skills has five principles: developing 2Ist century skills, integrated-focus, actual and contextual, flexible, and feasible. Apart from being developed according to Permendikbud number 22 of 2016, the syllabus should also develop 2Ist century skills (Dewi \& Purwanti, 2019). One of the indicators of 2Ist century skills is developing basic competencies to become indicators of learning oriented towards students' higher order thinking skills (Istiqomah, 2018:185). Development should be focused on one skill so that the results are better and more efficient. Indicators were further developed in developing competency achievement indicators for students to implement in the form of learning activities. The IPK was further supported by the use of 2Ist century character and learning models. 
In addition, the syllabus should be integrated-focus, meaning that the thematic learning syllabus in elementary schools is arranged in an integrated manner to accommodate a network of themes between learning, literacy, and character education by focusing on one specific material topic. In this case the focus was on spelling learning. It is intended that students get meaningful learning. Meaningful learning makes students more active in exploring and determining scientific concepts that are broader and more comprehensive or holistic (Utami \& Hasanah, 20I3).

The syllabus must be actual and contextual. Actual means that all components covered in the syllabus should use the science and technology development approach. Contextual means that the development of the syllabus must be in accordance with the concept of the students' era. Learning experiences are arranged according to the life experienced by students (Zubaidi, 2015).

A flexible syllabus is also important to accommodate the diversity of students. The dynamics of change that occur in society also require a flexible syllabus (Satiti, 20II). The development of a syllabus with the principle of flexibility becomes the foundation of the teacher in preparing students for the current development. Students are prepared to survive according to the needs of the times.

The feasibility of the syllabus is measured based on the level of validity, practicality, and effectiveness (Helty et al., 2020). Validity is measured based on the correctness of syllabus development according to existing theories. A practical syllabus will make it easier for teachers to implement syllabus development. The effectiveness is intended so that the developed syllabus is able to have a positive influence on students, especially in this study, which is increasing higher order thinking skills through spelling learning.

2. Lesson Plan

Lesson plans are prepared based on the KD of a particular school (Kosasih, 20I4:I55). A lesson plan is a plan that is arranged systematically. Based on the results of the FGD, teachers were not familiar with the one-sheet lesson plan. Teachers need a contextual lesson plan model that focuses on one material but is presented thematically and integratively.

A lesson plans is prepared based on the Minister of Education and Culture's Circular Letter Number 16 of 2019 which consists of learning objectives, learning steps, and assessments. Learning objectives are formulated using KKO "menandai", "memerinci", "menganilisis", "memperbaiki", and "melakukan". The five KKOs were translated into four lessons containing Bahasa Indonesia learning content. Condition yang disyaratkan berupa kegiatan diskusi, membaca, menyimak video, dan pembiasaan. Degree yang diukur dalam perangkat pembelajaran berupa sikap tertib, kerjasama, keruntutan, kebenaran, dan sistematis.

The learning steps consist of initial activities, core activities, and final activities. Initial activities include a) physical and psychological conditioning of students; b) students are given motivation in learning through the objectives to be achieved in the learning carried out, lesson plans, and assessments; and c) making apperception by asking questions about the environment around students and linking it to the learning theme on that day.

The core activity described the development of activities based on the learning models that have been determined in the syllabus which are in the form of DL, PBL and project based learning model. Learning used a thematic approach. The material in each subject matter was tied into one theme regarding the environment. Natural science, social studies, and PPKn subject were as the content of reading text. Material on Bahasa Indoensia were with spelling as the main material. Learning activities were carried out in groups.

Skill competencies were obtained through a series of learning activities derived from the syntax of the learning model used. The basic competencies of reporting interview results were then elaborated through the activities of compiling interview texts, completing gaps in interview texts, compiling random interview reports, and writing interview reports. Skills competencies were taught in stages from prerequisite indicators to compile and complement. Writing interview reports was as a key indicator. Prerequisite indicators allow students to find spelling conventions in group discussions.

In the closing activity, the teacher concluded the lesson on that day. Next, the teacher conducted a daily assessment. The teacher also provided feedback on the learning activities on that day. Then the teacher followed up on the lesson on that day. Finally, the teacher took time to reflect.

Assessment was carried out on each lesson content. Assessment of knowledge and skills competencies was carried out on the subject content of Bahasa Indonesia, Natural Science, and Social Studies. Assessment of spiritual and social competence is assessed on the PPKn lesson. Assessment of spelling learning content of Bahasa Indoensia learning competence was assessed by a multiple choice written test. Skills competencies were assessed by performance in the form of an assessment rubric. The following is the I page lesson plan in lesson 3. 


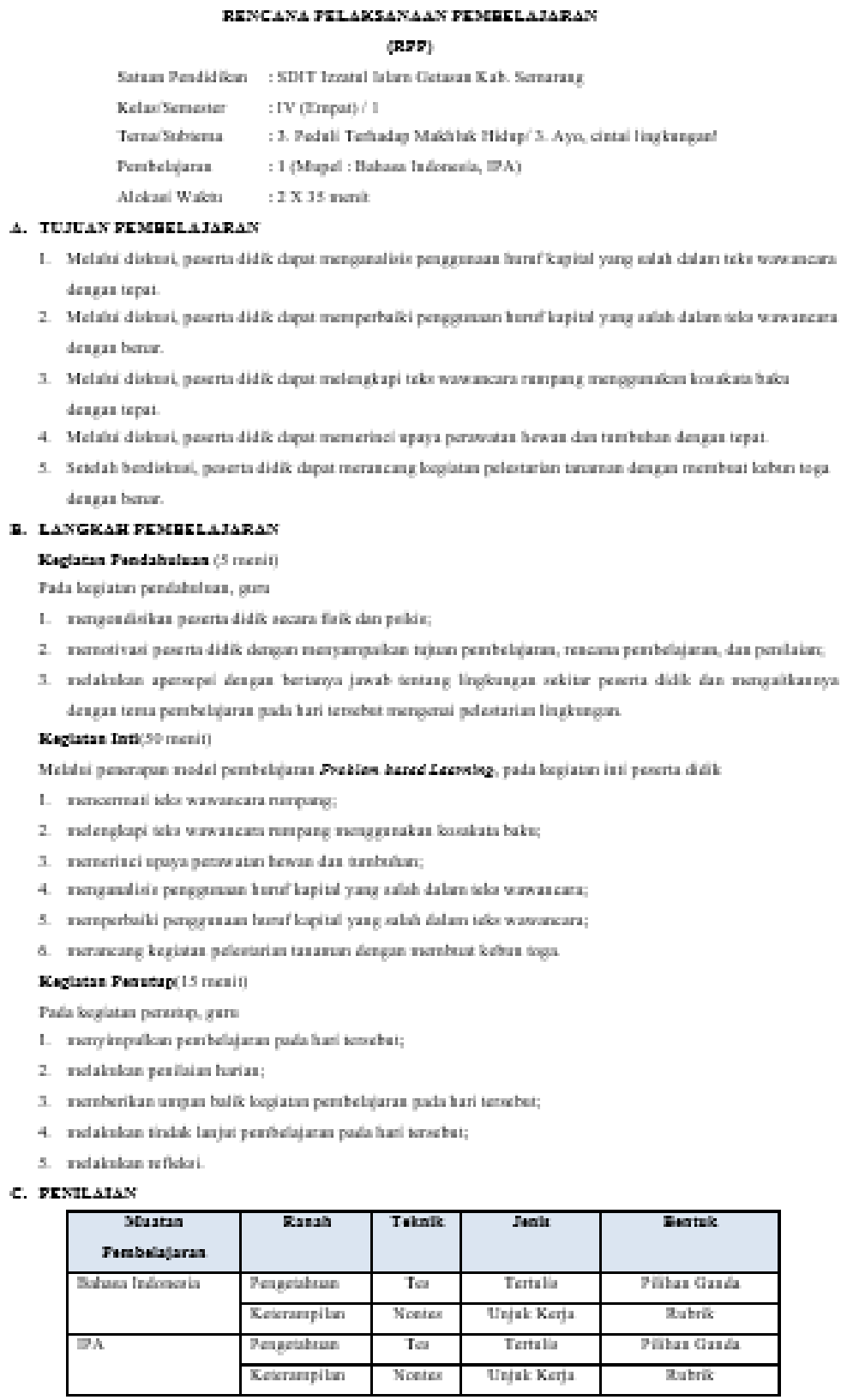

Figure 2. The Lesson Plan of Learning Spelling

Based on the results of expert validation, the lesson plan assessment was declared very valid by learning experts with a percentage of $92.86 \%$. The material expert gave a RPP assessment score with an average of $93.57 \%$. This shows that the lesson plan fulfills the very feasible criteria to be implemented and is able to improve the higher order thinking skills of elementary school students.

The learning spelling lesson plan that improves higher order thinking skills has 3 characteristics: integrated, deep, and contemporary. First, integrity is a bridge to explore students' needs. Integrity includes integration between lessons and literacy activities as well as character assessment. In addition, integrity is also related to language activities with a thematic approach. Learning spelling combined language material, thematic approaches, character assessment, literacy, and student needs. integrity makes students actively participate in constructing knowledge about spelling. Students' activeness is strived by using 2Ist century learning models in the process of learning activities. Integrity is one of the keys to successful sustainable learning planning (Driscoll, 2013).

The second characteristic is 'deep'. The lesson plan for spelling learning was presented thematically with the main focus on spelling as a material for deepening learning. 'Deep' also refers to the thinking process of students from the conceptual level to metacognition. The lesson plan consisted of learning objectives, learning steps, and assessments. The learning objectives are the elaboration of the prerequisite IPK, key IPK, and enrichment IPK (Filia et al., 2019). In-depth material was presented integrally, starting from easy to deepening complex material. 
The contemporary characteristic refers to the context of the lesson plan that suits the needs of the times to prepare students to have 2Ist century competences. Therefore, learning objectives, learning activities, and assessments should refer to 2Ist century learning concepts. The formulation of learning objectives consists of audience, behavior, condition, and degree. Audience is the subject and object of learning which is students. Behavior refers to behavior that is planned to provide learning experiences to students using $\mathrm{KKO}$. The $\mathrm{KKO}$ chosen was $\mathrm{KKO}$ which required students to think at a higher order, such as analyzing mistakes, correcting mistakes, and creating ideas by writing interview reports according to the correct spelling. Condition is the condition of students before or after carrying out activities written using verbs that help students have 2Ist century competence, for example having discussions, listening to videos, and so on. Degree is the level of mastery of students after going through a series of learning processes. Degree was developed with a level of mastery or behavior that reflects 2Ist century competence, such as being independent, responsible, creative, and so on.

3. LKPD

LKPD is a guide for core learning activities. LKPD contains tasks that must be done by students; besides it also contains guidelines for doing these assignments that have been adjusted to KD and indicators of learning outcomes (Trianto, 2010). Based on the results of the FGD, teachers were not used to developing LKPD as a support for teaching materials for student activities. The teachers needed a spelling learning LKPD model that can be applied to improve higher-order thinking skills.

LKPD was prepared based on the basic framework for drafting LKPD. Learning objectives were translated into various forms of activities that can be carried out by students. LKPD was arranged according to the scope of activities in each lesson. LKPD consisted of identity and worksheets. Worksheets consisted of instructions, illustrations, reading material, and a series of student discussion materials. LKPD was accompanied by an image printed in full color. LKPD used font size I2 and a variety of fonts. The students did the LKPD in groups.

LKPD is prepared for each lesson. In lesson I, students looked for the use of spelling in the interview text fragments to find various spelling rules. The content of natural science material is used as reading material for students. In addition, there was also an LKPD with activities to sort the interview texts. In lesson 3, students actively used LKPD to complete gaps in interview texts and to correct the use of capital letters. In lesson 4, the students used LKPD in completing the use of punctuation marks in the interview text and sorting random interview reports. LKPD in learning 6 activated students to conduct interviews and write interview reports. The following is a piece of LKPD in learning $I$.

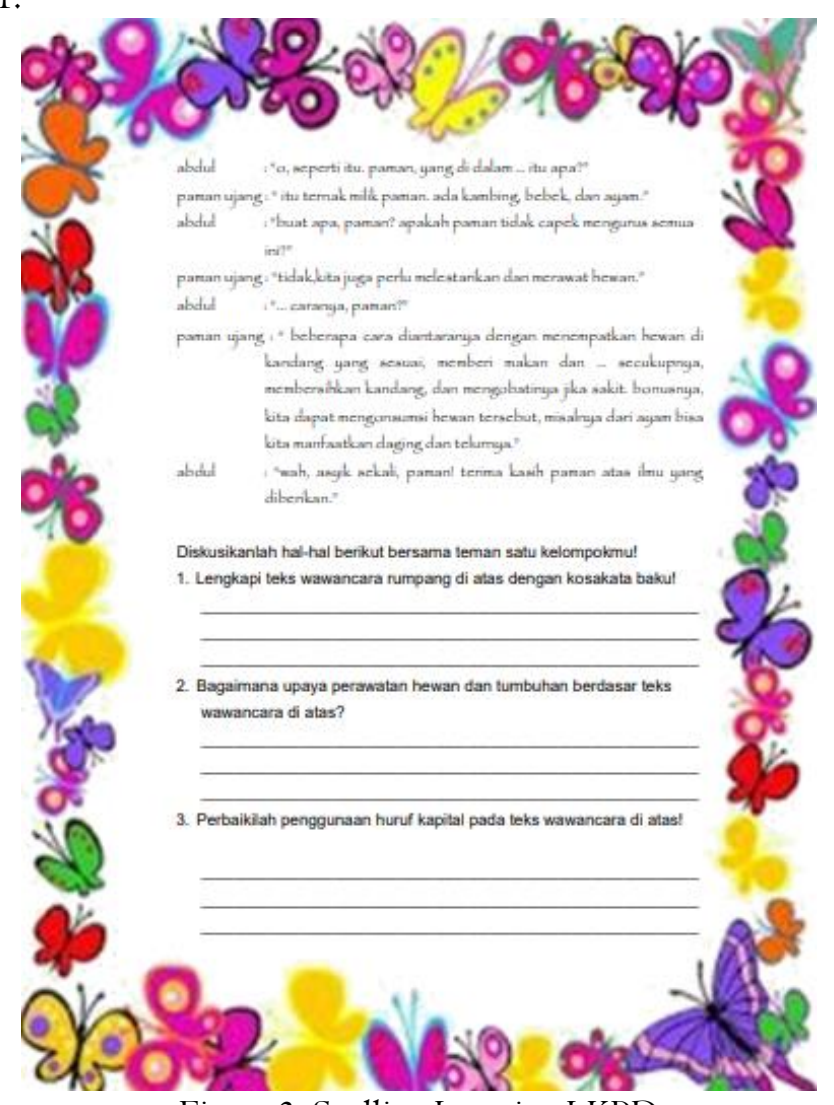

Figure 3. Spelling Learning LKPD 
Based on the results of expert validation, the LKPD assessment was declared very valid by learning experts with a percentage of $94.44 \%$. The material expert gave score of the lesson plans with a mean of $82.22 \%$. This shows that LKPD met the appropriate criteria to be implemented in higher-order thinking-oriented learning in elementary schools.

There were three characteristics of LKPD in spelling learning oriented to higher order thinking skills in elementary schools: focus, activating students, and interesting. LKPD that focused on predetermined goals was very important so that the results expected by students were appropriate. Thematic was only a bridge, but the focus of learning remains focused on learning spelling. Activity steps must focus on learning objectives.

LKPD must make students active. To activate students, the LKPD should contain several fun student activities to increase student activity. Every step in LKPD is student-centered (Rozi \& Suparman, 2019). Therefore, LKPD must also be made in accordance with the students' stages of thinking. Pradita \& Wangid (2017) argued, one of the proper LKPD assessment criteria for elementary school students was attractive in appearance. The presentation and adjustment of characteristics based on students' cognition has an important role in LKPD at the elementary school level. LKPD which does not contain too much writing, is equipped with illustrations, is colorful, and has the appropriate choice of type of letters; is part of its special attraction for students. At that LKPD, students will construct new knowledge about spelling rules through discussion activities.

4. Assessment

One of the important components in pursuing higher order thinking learning is planning and presenting questions and answers that can improve higher order thinking skills. The 2013 curriculum requires the use of authentic assessment. This assessment is one of the assessments that intends for students to take certain actions in expressing their attitudes, knowledge, and skills in real terms (Handono et al., 2016). The problem found in the field during the FGD was that the teachers' understanding was still low in making spelling assessments which integrated students' higher order thinking skills.

Planning a spelling learning assessment which is oriented towards improving higher order thinking skills in elementary school begins by compiling an assessment grid. The assessment grid contains an explanation of the assessment on aspects of the subject. Each subject plans an assessment by including KI and learning indicators. Learning indicators are developed into question indicators and the cognitive level is then analyzed.

The results of expert validation on the spelling learning assessment sheet were categorized as very feasible. This was evidenced by the learning experts' assessment with a percentage of $94.29 \%$ and material experts with $95.71 \%$. This percentage indicated that the assessment of spelling learning was very feasible to test the quality of spelling learning outcomes oriented towards improving higher order thinking skills in elementary schools.

The consequence of the implementation of spelling learning oriented towards improving higher order thinking skills in elementary school is that the assessments carried out also reflect higher order thinking skills. Aspects that are measured are restating and processing. Spelling learning is oriented towards improving higher order thinking skills in elementary schools which has special characteristics: contextual stimulus and holistic.

Cognitive assessments used contextual problems based stimuli. Stimuli were useful for encouraging higher order thinking processes. The stimuli must be contextual, interesting, novel, and familiar. In thematic learning, contextual problems are taken from other learning contents that are tied to a theme, for example about the environment. The questions used to measure students' higher order thinking skills can be stimuli in the form of reading; for example reading in the form of texts, paragraphs, case studies, pictures, graphics, photos, formulas, tables, examples, films, and so on which originated from daily life problems which were contextual with students. Such an assessment is intended so that students can get real situation-based assessments so that students can integrate the concepts learned at school in their lives (Batubara \& Sudrajat, 2019).

Comprehensive assessment allows coverage of all aspects of evaluation activities. Setiadi (2016) added that the assessment was carried out explicitly in three domains: the cognitive domain, the affective domain, and the psychomotor domain. A thorough assessment makes children's talents fully explored. In addition, complex language skills require diverse and comprehensive assessments so that the assessment is able to describe students' language skills in real terms.

Assessments also used various methods, for example questions in the form of multiple choice answers and questions with descriptive answers. Questions in the form of multiple choice answers were arranged with multiple choice questions and answers. The multiple choice was also structured with decoys. The answer key was presented implicitly. Students in answering questions were led to use stimulation or reading, with the knowledge that students previously had and used their reasoning. The questions in the form of explanatory answers, on the other hand, encouraged students to answer questions in a written form based on their knowledge from all the material which they had learned before, which in the context of this study is spelling material. This aimed to avoid unclear questions 
and facilitate scoring guidelines. The description questions are presented in the LKPD as a skills assessment. The assessment using multiple choice questions was used as the final evaluation of learning.

\section{Conclusion}

It can be concluded that each spelling learning tool oriented towards improving higher order thinking skills in elementary schools had special characteristics. The syllabus' characters were: developing 2Ist century skills, focus-integrated, actual and contextual, flexible, and feasible. Lesson plans also had unique characteristics which are: integrated, deep, and contemporary. LKPD had the characteristics of: focus, activate students, and be interesting. Last, assessments were characterized by contextual stimuli and holistic.

\section{Acknowledgement}

Thank you to the Indonesian Language Education Master Program FKIP UMS, PBI FKIP UMS, and SDIT Izzatul Islam Getasan Kab. Semarang which have collaborated well for this research.

\section{References}

Akbar, S. (2013). Instrumen Perangkat Pembelajaran. Remaja Rosdakarya.

Anderson, L. W., \& Krathwohl, D. R. (2015). Kerangka Landasan untuk Pembelajaran, Pengajaran dan Asesmen. Pustaka Pelajar.

Ariyana, Y., Pudjiastuti, A., Bestary, R., \& Zamroni. (2019). Buku Pegangan Pembelajaran Berorientasi pada Keterampilan Berpikir Tingkat Tinggi. Direktorat Jendral Guru dan Tenaga Kependidikan Kementerian Pendidikan dan Kebudayaan.

Batubara, U. N., \& Sudrajat, A. (2019). Teknik Penyusunan Instrumen Penilaian Higher Order Thinking Skill (Hots) Dalam Pembelajaran Sejarah. Lentera Pendidikan : Jurnal Ilmu Tarbiyah Dan Keguruan, 22(2), 335. https://doi.org/I0.24252/1p.2019v22n2iI5

Dewi, K. P., \& Purwanti, S. (2019). Integrasi kecakapan abad 2I dalam rencana pelaksanaan pembelajaran sekolah dasar. Seminar Nasional Hasil Pengabdian Kepada Masyarakat Universitas Ahmad Dahlan, September, 465472.

Driscoll, E. (2013). A lesson plan for sustainability. American Journal Of Business Education, 6(2), 44-48. https://clutejournals.com/index.php/AJBE/article/view/769I/7756

Filia, U., Sarjuni, \& Shidiq, G. (2019). Keterampilan Guru Pai Dalam Mengembangkan Rpp ( Studi Kasus Di Sma. Conference on Islamic Studies (CoIS ), 292-3I0. http://1ppmunissula.com/jurnal.unissula.ac.id/index.php/cois/article/view/800I/3642

Handono, S., Sufanti, M., Wahyudi, A. B., Hidayat, M., Budiarto, S., Suwarni, \& Wibowo, T. (2016). Bahan Ajar Bahasa Indonesia di Sekolah Dasar. Balai Bahasa Jawa Tengah.

Helty, Putra, D., \& Monalisa. (2020). Validasi Desain Silabus Writing II untuk Program Studi Bahasa Inggris. O4(I). https://online-journal.unja.ac.id/titian/article/view/9558/5562

Heni, D. N., Binadja, A., \& Sulistyorini, S. (2015). Pengembangan Perangkat Pembelajaran Tematik Bervisi Sets Berkarakter Peduli Lingkungan. Journal of Primary Education, 4(I), 30-35. https://journal.unnes.ac.id/sju/index.php/jpe/article/view/6919/4962

Hidayah, N. (2015). Pembelajaran Tematik Integratif di Sekolah Dasar. Terampil Pendidikan Dan Pembelajaran Dasar, 2(I), 34-49. https://doi.org/https://doi.org/I0.24042/terampil.v2iI.I280

Istiqomah. (2018). Pembelajaran dan Penilaian Higher Order Thingking Skills. Pustaka Mediaguru.

Julistiawati, R., \& Yonata, B. (2013). Keterampilan Berpikir Level C4, C5, \& C6 Revisi Taksonomi Bloom Siswa Kelas X-3 SMAN I Sumenep Pada Penerapan Model Pembelajaran Inkuiri Pokok Bahasan Larutan Elektrolit dan Non Elektrolit. UNESA Journal of Chemical Education, 2(2), I-II. https://jurnalmahasiswa.unesa.ac.id/index.php/journal-of-chemical-education/article/view/2730/I629

Kosasih, E. (2014). Strategi Belajar dan Pembelajaran Implementasi Kurikulum 2013. Yrama Widya.

Miles, M. B., Huberman, A. M., \& Saldana, J. (2014). Qualitative Data Analysis. sage.

Narayanan, S., \& Adithan, M. (2015). Analysis Of Question Papers In Engineering Courses With Respect To Hots (Higher Order Thinking Skills). American Journal of Engineering Education (AJEE), 6(I), I-IO. https://doi.org/I0.19030/ajee.v6iI.9247

Pradita, N. E., \& Wangid, M. nur. (2017). Pengembangan LKPD Tematik-Integratif Berbasis Karakter Pada Peserta Didik Sekolah Dasar. Jurnal Pendidikan Karakter, I(I), 56-70. 
https://journal.uny.ac.id/index.php/jpka/article/view/I5500/9693

Prihantini, A. (2015). Master Bahasa Indonesia. PT Bintang Angkasa.

Rozi, F., \& Suparman. (2019). Deskripsi E-LKPD untuk Membangkitkan Berpikir Kritis Peserta Didik Melalui Pembelajaran Discovery Learning. Proceedings Of The Ist STEEM 20I9, I(I), 84-90.

Rulviana, V. (2020). Analisis Kesalahan Penggunaan Huruf Kapital Pada Penulisan Karangan Narasi Siswa Sekolah Dasar. Juornal of Teaching and Learning Research, 2(I), I-6. https://doi.org/I0.24256/jtlr.v2iI.I33I

Satiti, K. (20II). Pendampingan Pengawas Sekolah Untuk Meningkatkan Kemampuan Guru Menyusun Silabus. Jurnal Ilmiah Guru COPE, 2(XVI), 9-16.

Setiadi, H. (2016). Pelaksanaan penilaian pada Kurikulum 2013. Jurnal Penelitian Dan Evaluasi Pendidikan, 20(2), I66-I78. https://doi.org/I0.2183I/pep.v20i2.7I73

Sufanti, M., Santoso, J., Fatimah, N., \& Pratiwi, D. R. (2017). Silabus dan Rencana Pelaksanaan Pembelajaran Bahasa Indonesia, Teori dan Praktik. Muhammadiyah University Press.

Sufanti, M., Wahyudi, A. B., Riyanto, S., Haryanti, T., Adzim, S., \& Susanti, D. (2017). Materi Ajar Teks Bahasa Indonesia di Sekolah Dasar (A. B. Wahyudi (ed.); Ist ed.). Bukukatta.

Sugiyono. (2015). Metode Penelitian Pendidikan. Alfabeta.

Supriyana, A., Azmin, G. G., Nureriyani, R., \& Rahmawati, A. (2016). Pelatihan Penggunaan Ejaan Yang Disempurnakan Dan Kalimat Efektif Pada Penulisan Surat Resmi Bagi Guru Sekolah Dasar Di Jakarta Timur. Sarwahita, I2(I), 5-I0. https://doi.org/I0.21009/sarwahita.I2I.02

Susanto, J. (2012). Pengembangan Perangkat Pembelajaran Berbasis Lesson Study dengan Kooperatif Tipe Numbered Heads Togetheruntuk Meningkatkan Aktivitas dan Hasil Belajar IPA di SD. Journal of Primary Educational, I(2). https://journal.unnes.ac.id/sju/index.php/jpe/article/view/785/8I I

Tarigan, H. G. (2009). Pengajaran Ejaan Bahasa Indonesia. Penerbit Angkasa.

Trianto. (2010). Model Pembelajaran Terpadu. Bumi Aksara.

Utami, I. H., \& Hasanah, A. (2013). Kompetensi Profesional Guru Dalam Penerapan Pembelajaran Tematik Di SD Negeri Maguwoharjo I Yogyakarta. Pionir Jurnal Pendidikan, I-II. https://jurnal.arraniry.ac.id/index.php/Pionir/article/view/6232/3809

Zubaidi, A. (2015). Model-Model Pengembangan Kurikulum dan Silabus Pembelajaran Bahasa Arab. Cendekia: Jurnal Kependidikan Dan Kemasyarakatan, I3(I), I07. https://doi.org/I0.2I I 54/cendekia.vI3iI.240 